\title{
Strategy For Handling Fishermen's Slums in Galesong, Takalar Regency Based on Community Participation
}

\author{
Dzulqarnain Aras ${ }^{1}$ \\ ${ }^{1}$ Lecturer in Regional and Urban Planning, Faculty of Engineering, \\ ${ }^{1}$ University of Muhammadiyah Bulukumba, Indonesia. \\ Email: 'dzulqarnainaras@umbulukumba.ac.id
}

\begin{abstract}
Slums as urban phenomenon is one of the problems faced in urban development Metropolitan MAMMINASATA reconditioned the process of urban development indirectly in the dynamics of developing slum areas in the District Galesong. This research

Keywords

Slums, Community Participation, Handling Strategies. aimed to investigate the typology of the development of slums and the sustainable handling strategy of the settlement. The research approach of the quantitative research used the descriptive and quantitative method and SWOT analysis. The research results indicted that the typology of the slums settlement in Galesong sub-district was the heavy typologi of the slums settlement, which was dominated by poor community and the minimum availability of the adequate infrastructure. Consequently, the communityparticipation-based handling strategy was needed to handle the slums settlement through the empowerment the participation in increasing the quality of slums settlement.
\end{abstract}

\section{INTRODUCTION}

The development of urban settlement areas, in general, is often problematic, in terms of the number of units built and indicated that it is not proportional to the population growth rate, including the quality of residential buildings which are considered not to meet livable quality standards, aesthetic requirements and fulfill adequate infrastructure (Salusu, 2015). The formal definition of urban areas in Indonesia is an area that has non-agricultural main activities with the composition of the function of the area as a place for urban settlements, centralization and distribution of government services, social services and economic activities (Law No.26 of 2007 concerning spatial planning). Symptoms of urban sprawl or urban sprawl have appeared on the surface, and it is feared that it can cause a decrease in environmental quality in the city and its suburbs (Ihsan, 2012). Urban Sprawl Pattern according to Oeslati et al., 2015; Dadi et al., 2016; Ewing et al., 2017 in Giyasih (2017), namely (1) concentric, (2) ribbon/linear/axial, and (3) development of a jump or chessboard.

According to Giyasih (2017), the physical indication of urban sprawl in agricultural areas is marked by the conversion of agricultural land to non-agriculture. Before indications of urban sprawl exist in an area, land use is dominated by vegetation cover. However, urban sprawl causes the dominant land use to change from vegetation cover to building coverage or built up area. Likewise with the urban sprawl of the coastal marine area, of course, it is indicated that there is a conversion of sea coastal land into settlements. Based on the criteria for slum settlements from the Minister of Public Works and Public Housing No. 2/PRT/M/2016 concerning improving the quality of slum housing and slum settlements, on 7 indicators of settlement infrastructure, namely: buildings, environmental roads, drinking water, environmental drainage, waste water management, waste management and fire protection.

The fishing community is part of the coastal community. Theoretically, coastal communities are defined as people who live and carry out socio-economic activities related to coastal and oceanic resources (Fisu \& Marzaman, 2018). However, spatially coastal communities can be defined as people who live spatially in coastal areas without considering whether they have socio-economic activities related to the potential and condition of coastal and ocean resources (Fisu, 2016).

Takalar Regency is an area that has enormous potential for coastal resources, located along the west coast of the Makassar Strait to the southern coast of the Flores Sea and its capital is Patallassang. One of the coastal areas in Takalar Regency which has a lot of potential for coastal resources is Galesong District. One of the phenomena of slum settlements on the coast in Takalar Regency is in the Boddia Fisherman's Environment and the Bayowah Environment of Galesong District. The fishing village is located on the west coast of Takalar 
district which is directly adjacent to Makassar Bay. The village is also adjacent to the Makassar City. The data shows that $81 \%$ of the people work in the fishery sector, such as fishermen, fish sellers, captains, and skipper/palele/ponggawa.

The coastal area management initiative, Galesong Selatan District, Takalar Regency requires a positive response from every main actor in each locality. The response in question is not only about readiness to accept this initiative, but also constitutional readiness at the local level, community readiness which is revealed in the form of joint action readiness, in this case readiness at the community or coastal community level in Galesong District, Takalar Regency. This challenge is increasingly real in coastal and marine areas, where integrated management is required to achieve a balance between meeting economic needs and protecting environmental quality, especially the surrounding fishing communities.

With the above background in mind, a sustainable development model known as sustainable development will emerge which contains three main elements which include economic, ecological and social dimensions (Harris et al, 2001 in Dahuri, 2003). A coastal area development, firstly it is considered economically sustainable (economic growth) if the area is able to produce goods and services in a sustainable manner; Second, it is considered ecologically sustainable when the base of the availability of natural resources can be maintained in a stable manner, there is no over-exploitation of renewable natural resources, there is no waste disposal that exceeds the assimilation capacity of the environment which can lead to polluted conditions, and the use of resources that cannot be utilized. renewed, coupled with the development of adequate substitute materials, and thirdly it is considered socially sustainable (social equity) if the basic needs of the entire population are met; there is a fair distribution of income and business opportunities.

Based on the description above, it is necessary to handle slum areas in anticipating various problems caused by the spread of slums in Takalar Regency, therefore the researchers took the research title 'Strategies for Handling Fishermen Slum Settlement' (Case Study: Fishermen Slum Settlement in Galesong District, Kabupaten Takalar).

\section{LITERATURE REVIEW}

\subsection{Definition of Slums}

Settlement is a place for human life not only regarding physical and technical aspects but also social, economic, cultural aspects and its inhabitants. It's not only about quantity but also quality. It does not only concern a place to live at home, but also a place to work, shop and relax (Alfian 2014).

Based on Law No. 1 of 2011 concerning housing and settlement areas, there are the following definitions:

1. A house is a building that functions as a suitable place to live, a means of fostering a family, a reflection of the dignity and worth of its occupants, as well as an asset for its owner.

2. Housing is a collection of houses as part of settlements, both urban and rural, which are equipped with infrastructure, facilities, and public utilities as a result of efforts to fulfill livable houses.

3. Settlements are part of a residential environment consisting of more than one housing unit that has infrastructure, facilities, public utilities, and has supporting activities for other functions in urban areas or rural areas.

4. Slums are settlements that are unfit for habitation due to irregularity of buildings, high levels of building density, and the quality of buildings and facilities and infrastructure that do not meet the requirements.

Slum settlements continue to arise influenced by several driving factors such as the increase in population which continues to increase every year resulting in the need for housing to increase. In addition, the flow of urbanization to cities resulted in more and more land needed to build houses. Urbanization occurs because of efforts to improve economic conditions in urban areas in the hope of being able to meet the needs of daily life. But in reality not all urbanization can bring benefits and advantages. Part of the failure of urbanization has actually created new problems in urban areas such as the emergence of slum settlements which are usually inhabited by low-income people (MBR). On average, MBR have a low level of education and their skills are also low.

\subsection{Characteristics of Slums}

According to Siswono Yudohusodo in his book Houses for all the People, suggests that slums are residential neighborhoods that have the following characteristics: 
1. Environmental physical conditions that do not meet technical and health requirements, namely the lack or unavailability of infrastructure, facilities, environmental facilities. Even though they exist, they are in very poor condition and in addition, the layout of the buildings is disorganized;

2. The condition of the building is very bad and the building materials used are semi-permanent building materials;

3. The density of buildings with a KDB that is greater than the allowable, with a very high population density (more than 500 people per ha); and

4. Mixed and disorganized city functions.

The characteristics of slums according to Law No. 1 of 2011 concerning housing and settlement areas are:

1. Irregularity and high density of buildings;

2. Incomplete infrastructure, facilities and public utilities;

3. 3 Decrease in the quality of houses, housing and settlements, as well as infrastructure, facilities and public utilities; and

4. Construction of houses, housing and settlements that are not in accordance with the regional spatial plan.

The stage of identifying the characteristics of slum settlements by means of in-depth identification, this identification step is very important to do before the process of formulating directions in research (Fitria \& Setiawan, 2014).

According to Nursyahbani and Pigawati (2015), the characteristics of the community in slum settlements are called the characteristics of the occupants. The characteristics of the occupants are the characteristics of the community that can be judged from the social and economic conditions. The characteristics of the occupants of the social conditions can be seen from the level of education and the type of work of the community. Where the level of education and type of work will affect the condition of the building and the environmental conditions inhabited. In addition to these two factors, population density and the number of residents can also affect the existing environmental conditions. As for the economic condition, it can be seen from the community in meeting their daily needs as well as the way in allocating funds to repair houses and the environment. In addition, according to Budi Prayitno (2014), the characteristics of people in slums can be seen from the level of income of the community and the level of community educators in slum settlements is low.

The characteristics of slum communities according to the Directorate General of Regional Development of the Ministry of Home Affairs are the dominance of slum residents with low income and education, and in slum settlements, the population works in the informal sector. Meanwhile, according to Sri Kumala (2014), the characteristics of slum communities can be seen from the economy of people with low incomes, people who work in the informal sector, and low levels of public education.

\subsection{Society participation}

Community participation is community involvement in the development of themselves, their lives, and their environment (Astuti, 2017). The notion of participation is always associated with the participation of a scientist named Keith Davis in Warjio \& Sigalingging (2014), suggesting that participation can be defined as mental involvement or thoughts or morals or feelings in group situations that encourage them to contribute to the group in an effort to achieve goals. and take responsibility for the business concerned.

According to Gordon W. Allport in Warjio \& Sigalingging (2014), states that a person who participates actually experiences his or her ego involvement which is more than just involvement in work or tasks. There are three important elements in participation, namely:

a. Participation is a mental and emotional involvement, more than merely physical involvement.

b. Availability contributes something to the effort to achieve group goals.

c. There is an element of responsibility.

The above definition implies that participation is a process of participation, involvement and togetherness of community members in making a decision. Community involvement, either directly or indirectly, can be considered as a form of community participation in participating.

Community participation has many forms, ranging from direct public participation in government programs and indirect ones such as donations of funds, energy, thoughts, and opinions or even rejection in government policy making. So far, community participation is still limited to participation in the implementation of government programs or activities, even though community participation is not only needed at the time of implementation, but starting from the planning stage to decision making (Rorong, et al., 2017). 
According to Cohen and Uphoff in Astuti (2013), there are four types of participation, namely participation in decision making, participation in implementation, participation in utilization and participation in evaluation.

a. Participation in decision making.

This participation is mainly concerned with determining alternatives with the community regarding ideas or ideas that concern common interests. The forms of participation in decision making include contributing ideas or thoughts, attending meetings, discussions and responding or rejecting the programs offered. Two approaches in the SPPN are top-down and bottom-up participatory development planning. The second type of approach intends to involve all stakeholders in development, to get aspirations and create a sense of belonging. This approach is implemented according to government levels through deliberation held at the national, provincial, district/city, sub-district, and village levels. At the village level, this deliberation is called the Village Development Planning Deliberation (Suroso, et al., 2014).

b. Participation in implementation.

Participation in implementation includes mobilizing financial resources, administrative activities, coordination and program elaboration. Participation in implementation is a continuation of the plans that have been initiated previously, both related to planning, implementation and goals.

c. Participation in benefit-taking.

Participation in taking benefits in terms of quality can be seen from the output, while in terms of quantity it can be seen from the percentage of program success.

d. Participation in evaluation.

Participation in this evaluation is related to the implementation of the previously planned program. Participation in this evaluation aims to determine the achievement of the previously planned program.

\subsection{Slums Handling}

In handling slum settlements, it is necessary to know the needs of the area and the root of the problem, so that the right direction can be formulated. To be able to find out the right pattern of handling, first it is necessary to know how the slum level is based on several assessment criteria, so that the class of the slum settlement area can be known (Andini, 2013).

The general scheme for formulating concepts and strategies for improving the quality of slum settlements refers to Law No. 1 of 2011 and PUPR Ministerial Regulation No. 2/PRT/M/2016. According to Basri et al. (2010), the rejuvenation model is a model that can be used as a reference to improve settlements that are experiencing environmental degradation. Urban rejuvenation programs are usually intended to transform slum areas by filling and building infrastructure and facilities according to their land use so that they are suitable for residents to inhabit as well as to accommodate other activities and at the same time beautify the appearance (face) of the city (Hariyanto, 2010).

For slum settlements located on illegal land, the pattern of handling that must be done is resettlement. According to Johara T.J, in Basri et al. (2010), resettlement or resettlement is generally carried out through a transmigration program, namely the movement of people (migration) from an area that is generally densely populated on the island of Java to areas that are still sparsely populated usually outside Java with the aim of getting a better life. and is expected to increase national integration in the economy and social. Resetlement is still a pre-village, which is lower level than self-help villages, namely settlements of small and scattered residents, whose residents have not settled in a place called a village.

Resetlement or resettlement of residents in a specially provided area. Displacement of people usually takes time and has considerable social costs, including the possibility of growing riots or community unrest. This relocation is if the settlement is in a functional area that will/needs to be revitalized so as to provide economic value for the district/city government.

Based on the Guidelines for Implementing Settlement Infrastructure, Handling Settlement Areas (PUPR, 2015), the components and types of quality improvement activities consist of restoration and rejuvenation activities.

\section{RESEARCH METHOD}

\subsection{Types of Research}


The research was conducted by direct observation in the field and through interviews as well as accessing data at the relevant agencies. The research uses a descriptive quantitative and qualitative approach with the aim of describing the data collected systematically. This research was conducted by conducting interviews with people living in slums using questionnaires and direct observation of the existing infrastructure at the research site (Sugiyono, 2015).

\subsection{Research Time and Location}

The research time was carried out for 3 months, namely from August to October 2021. The research location was carried out in fishermen's slum settlements in Galesong District, Takalar Regency. In Galesong District, there are two location spots, namely the Boddia Environment and the Bayowah Environment, which are located in the Boddia Village/Sub-district and Galesong City, respectively.

\subsection{Population and Sample}

Based on the Decree of the Takalar Regent regarding the determination of the slum area of Takalar Regency, the slum area of Takalar Regency consists of ten neighborhoods which administratively are spread over seven sub-districts including Pattalasang District, South Galesong District, Galesong District, Galesong District. Therefore, the researchers determined the research population, namely 2 slum locations, namely: Kelurahan Boddia (Boddia Fishermen's Neighborhood) and Kelurahan Galesong Kota (Bayoah Neighborhood) with a total number of households in the slum settlements of the 2 wards is 939 families.

Researchers determined 2 residential neighborhoods that were categorized as slums in Galesong District, Takalar Regency. In determining the number of samples in this study, using the Taro Yamane formula as follows:

$$
\begin{aligned}
& \mathrm{n}=\frac{\mathrm{N}}{\mathrm{N}(\mathrm{d})^{2}+1} \\
& \mathrm{n} \quad=\text { number of samples } \\
& \mathrm{N}=\text { total population } \\
& \mathrm{d}=\text { standard error used }(0,1) \text {, with the expected error rate in the study is } 10 \text {, then: } \\
& \mathrm{n}=\frac{939}{939(0,1)^{2}+1} \\
& \mathrm{n}=\frac{939}{939(0,01)^{2}+1} \\
& \mathrm{n}=\frac{939}{10,29} \\
& \mathrm{n}=91,2 \\
& \mathrm{n}=91 \mathrm{KK} \text {. }
\end{aligned}
$$

\subsection{Data Analysis Technique}

To analyze the management of slums, this study uses qualitative and quantitative descriptive analysis methods. For more details, the analysis method in this research data is as follows:

To answer the formulation of the first problem, namely how the characteristics and typology of slum settlements in Galesong District, Takalar Regency, used descriptive qualitative and quantitative analysis by observing the existing infrastructure in slum settlements. Observations were made by comparing appropriate technical standards based on the criteria for slum settlements from the PUPR Ministerial Regulation No. 2/PRT/M/2016 concerning improving the quality of slum housing and slum settlements, against 7 indicators of settlement infrastructure, namely: buildings, environmental roads, drinking water, drainage. environment, waste water management, waste management and fire protection.

To answer the second problem formulation, namely How to deal with fishermen's slum settlements in Galesong District, descriptive quantitative methods are used, assisted by a SWOT analysis tool. Methods for formulating strategies for handling slum areas of fishermen Galesong Kab. Takalar refers to the stages of strategy formulation techniques developed (David, 2009). The stages of strategy formulation as a framework are the input stage (the input stage), the matching stage (the matching stage) and the decision stage (the decision stage). For the input stage, an external factor evaluation matrix (EFE) and an internal factor evaluation matrix (IFE) are used. The EFE and IFE matrices are processed using several analytical steps. Identification of 
External and Internal factors, the first step taken is to collect information and identify external (opportunities and threats) and internal (strengths and weaknesses) factors related to the management of the Range Market by conducting interviews using questionnaires to experts. The results of the identification and analysis of the two factors above become external and internal determinants which are then given weights and ratings.

Determination of weights and ratings using a questionnaire by submitting the results of the identification of external and internal factors to the expert. The results obtained are knowing the strategic position and corporate strategy (Grand Strategy) of the development of residential areas. After the input stage, the matching stage is continued which is focused on generating feasible alternative strategies by combining external and internal factors resulting from the input stage (EFE and IFE matrices).

The analytical tool in this stage is the SWOT (Strengths - Weaknesses -Opportunities - Threats) matrix. This matrix combines the opportunities and threats faced according to their strengths and weaknesses to produce four alternative strategies, namely SO strategy, WO strategy, WT strategy and ST strategy. Next, the decision stage is the stage to determine which alternative strategies are feasible and best, using the Quantitative Strategies Planning Matrix (QSPM) analysis tool or the Quantitative Strategic Planning Matrix. QSPM uses the results of the analysis of the input stage and the matching stage. SWOT analysis using matrix analysis method. The results of this analysis will give birth to various strategies in handling the fishermen slum areas of Galesong Kab. Takalar. The residential area development strategy is formulated according to the variables studied, namely; Housing conditions, environmental roads, sanitation, and socio-economics. The strategy formulated is expected to be able to handle the Galeson fishermen's slum areas based on community participation.

This analysis is intended to identify internal and external factors which include: (1) Strengths are internal factors as a driving force to achieve the goal of developing coastal areas with a sustainable coastal resource management approach. (2) Weaknesses are identifying internal factors that will affect the achievement of the objectives of developing coastal areas with a sustainable coastal resource management approach. (3) Opportunities are external factors that support to achieve coastal area development with a sustainable coastal resource management approach. (4) Threats are identifying external factors that will affect the achievement of the objectives of developing coastal areas with a sustainable coastal resource management approach.

\section{RESULT AND DISCUSSION}

\subsection{Result}

Takalar Regency is one of the regencies in South Sulawesi Province which is located in the southern part. The astronomical location of Takalar Regency is at a position of 50 3' - 50 38' South Latitude and 1190 22' 1190 39' East Longitude, with an area of approximately $566.51 \mathrm{Km} 2$. The distribution of urban slums in Takalar Regency can be seen in Table 1. The condition of the existing buildings in the slums in the research location, seen from the arrangement of buildings, the level of density and the quality of the buildings.

Table 1. Distribution of Slums in Takalar Regency

\begin{tabular}{clll}
\hline No & \multicolumn{1}{c}{ District } & \multicolumn{1}{c}{ Village } & \multicolumn{1}{c}{ Slum Location Name } \\
\hline 1 & South Galesong & Bontokassi & Bontokassi Environment \\
2 & Galesong & Boddia & Boddia Fisherman Environment \\
3 & Galesong & Galesong Kota & Bayowah Environment \\
4 & North Bolombangkeng & Palleko & Palleko 2 Environment \\
5 & North Bolombangkeng & Bontolebang & Kampung Parrang Environment \\
6 & Pattallassang & Pappa & Pappa 1, 2 Environment \\
7 & Pattallassang & Pattalasang & Palemba Pattalasang Environment \\
8 & Pattallassang & Palantikang & Palantikang Environment \\
9 & Sandrobone & Sandrobone & Bontowa Environment \\
10 & Mangarabombang & Mangadu & Tamalate Environment \\
\hline
\end{tabular}

Source: Slum Profile of Takalar Regency, 2017.

The analysis refers to the Minister of Public Works and Public Housing No.2/PRT/M/2016 on improving the quality of slum housing and slum settlements. Based on Table 2 shows the value of public perception related to the condition of IMB ownership which shows 52 respondents have IMB and 39 do not have it, so that the distribution value of parameter 130 shows a moderate value. 
Table 2. Respondents' Perceptions Regarding Building Density Conditions

\begin{tabular}{cccccc}
\hline \multirow{2}{*}{ No } & Ownership & \multicolumn{2}{c}{ Slum Settlement District. } & \multicolumn{2}{c}{ Mark } \\
& IMB & N & Galesong & Parameter & Mark \\
\hline 1 & Yes & 52 & 57,14 & 1 & 52,00 \\
2 & Not & 39 & 42,86 & 2 & 78,00 \\
& Amount & 91 & 100,00 & 3 & 130,00 \\
\hline
\end{tabular}

Source: Primary Data Management Results

Incompatibility with buildings with technical requirements is reviewed based on the comfort of the community in living in the research location by looking at the condition of the building based on the PUPR Ministerial Decree No. 2/PRT/M/2016 concerning improving the quality of slum housing and slum settlements (Table 3). Table 3 shows the community's perception value regarding the comfort of the building at the research location which shows 29 respondents feel comfortable and 62 are not comfortable so that the distribution value of the parameter 153 shows a bad value. This condition is caused by the dominant semi-permanent housing condition with the building area not proportional to the number of people who occupy it and the building does not meet health standards (unfit for habitation).

Table 3. Respondents' perception of building comfort

\begin{tabular}{cccccc}
\hline \multirow{2}{*}{ No } & \multirow{2}{*}{$\begin{array}{c}\text { Building } \\
\text { Convenience }\end{array}$} & \multicolumn{2}{c}{ Slum Settlement District. } & \multicolumn{2}{c}{ Mark } \\
& $\mathrm{N}$ & $\%$ & Parameter & Mark \\
\hline 1 & Yes & 29 & 31,87 & 1 & 29,00 \\
2 & Not & 62 & 68,13 & 2 & 124,00 \\
& Amount & 91 & 100,00 & 3 & 153,00 \\
\hline
\end{tabular}

Source: Primary Data Management Results

The Galesong Slum Settlement Area is a slum area located in the Boddia fishing environment and the Bayowah neighborhood in Galesong City Village with an area of 34.92 hectares of delineation. Based on the characteristics, the Galesong slum area is a coastal slum area. The population in the Galesong slum area is 936 people divided into 187 families. The Assessment Formula in Determining the Priority Scale for Handling Urban Slums in Takalar Regency in Galesong Slums Area can be seen in Table 4.

Table 4. Assessment Formula in Determining Priority Scale for Handling Urban Slums in Takalar Regency in Galesong Slums Area

\begin{tabular}{|c|c|c|c|c|c|c|c|c|c|c|c|c|c|c|c|c|c|c|c|}
\hline \multirow{3}{*}{ Mark } & \multirow{3}{*}{$\begin{array}{c}\text { Informatio } \\
\mathbf{n}\end{array}$} & \multicolumn{18}{|c|}{ Various Classification Possibilities } \\
\hline & & A & A & A & A & A & A & B & B & B & B & B & B & $\mathrm{C}$ & $\mathrm{C}$ & $\mathrm{C}$ & $\mathrm{C}$ & $\mathrm{C}$ & $\mathrm{C}$ \\
\hline & & 1 & 2 & 3 & 4 & 5 & 6 & 1 & 2 & 3 & 4 & 5 & 6 & 1 & 2 & 3 & 4 & 5 & \\
\hline \multirow{2}{*}{\multicolumn{20}{|c|}{$\begin{array}{c}\text { Slum Level } \\
\text { (Total Grade A) }\end{array}$}} \\
\hline & & & & & & & & & & & & & & & & & & & \\
\hline $\begin{array}{c}71- \\
95\end{array}$ & Heavy Slum & $\mathbf{x}$ & $\mathbf{x}$ & $\mathbf{x}$ & $\mathbf{x}$ & $\mathbf{x}$ & $\mathbf{x}$ & & & & & & & & & & & & \\
\hline 45- 70 & $\begin{array}{l}\text { Moderate } \\
\text { Slum }\end{array}$ & & & & & & & $\mathbf{x}$ & $\mathbf{x}$ & $\mathbf{x}$ & $\mathbf{x}$ & $\mathbf{x}$ & $\mathbf{x}$ & & & & & & \\
\hline $\begin{array}{c}19- \\
44\end{array}$ & Light Slum & & & & & & & & & & & & & $\mathbf{x}$ & $\mathbf{x}$ & $\mathbf{x}$ & $\mathbf{x}$ & $\mathbf{x}$ & $\mathbf{X}$ \\
\hline
\end{tabular}




\begin{tabular}{|c|c|c|c|c|c|c|c|c|c|c|c|c|c|c|c|c|c|c|c|}
\hline \multirow{3}{*}{ Mark } & \multirow{3}{*}{$\begin{array}{l}\text { Informatio } \\
n\end{array}$} & \multicolumn{18}{|c|}{ Various Classification Possibilities } \\
\hline & & A & A & $\mathrm{A}$ & A & $\mathrm{A}$ & A & B & B & B & B & $\mathrm{B}$ & B & $\mathrm{C}$ & $\mathrm{C}$ & $\mathrm{C}$ & $\mathrm{C}$ & $\mathrm{C}$ & $\mathrm{C}$ \\
\hline & & 1 & 2 & 3 & 4 & 5 & 6 & 1 & 2 & 3 & 4 & 5 & 6 & 1 & 2 & 3 & 4 & 5 & 6 \\
\hline \multirow{2}{*}{\multicolumn{20}{|c|}{$\begin{array}{c}\text { Other } \\
\text { Considerations } \\
\text { (Total B Score) }\end{array}$}} \\
\hline & & & & & & & & & & & & & & & & & & & \\
\hline $7-9$ & $\begin{array}{l}\text { Other } \\
\text { Consideratio } \\
\text { ns High }\end{array}$ & $\mathbf{x}$ & $\mathbf{x}$ & & & & & $\mathbf{x}$ & $\mathbf{x}$ & & & & & $\mathbf{x}$ & $\mathbf{x}$ & & & & \\
\hline $4-6$ & $\begin{array}{l}\text { Other } \\
\text { Consideratio } \\
\text { ns Moderate }\end{array}$ & & & $\mathbf{x}$ & $\mathbf{x}$ & & & & & $\mathbf{x}$ & $\mathbf{x}$ & & & & & $\mathbf{x}$ & $\mathbf{x}$ & & \\
\hline $1-3$ & $\begin{array}{l}\text { Other } \\
\text { Consideratio } \\
\text { ns Low }\end{array}$ & & & & & $\mathbf{x}$ & $\mathbf{x}$ & & & & & $\mathbf{x}$ & $\mathbf{x}$ & & & & & $\mathbf{x}$ & $\mathbf{X}$ \\
\hline \multicolumn{20}{|c|}{$\begin{array}{l}\text { Land Legality } \\
\text { (Total Grade C) }\end{array}$} \\
\hline$(+)$ & \begin{tabular}{|l|} 
Legal Land \\
Status
\end{tabular} & $\mathbf{x}$ & & $\mathbf{x}$ & & $\mathbf{x}$ & & $\mathbf{x}$ & & $\mathbf{x}$ & & $\mathbf{x}$ & & $\mathbf{x}$ & & $\mathbf{x}$ & & $\mathbf{x}$ & \\
\hline$(-)$ & $\begin{array}{l}\text { Land Status } \\
\text { Illegal }\end{array}$ & & $\mathbf{X}$ & & $\mathbf{x}$ & & $\mathbf{x}$ & & $\mathbf{x}$ & & $\mathbf{x}$ & & $\mathbf{x}$ & & $\mathbf{x}$ & & $\mathbf{x}$ & & $\mathbf{x}$ \\
\hline \multicolumn{2}{|c|}{$\begin{array}{l}\text { Handling Priority } \\
\text { Scale }\end{array}$} & 1 & 1 & 4 & 4 & 7 & 7 & 2 & 2 & 5 & 5 & 8 & 8 & 3 & 3 & 6 & 6 & 9 & 9 \\
\hline
\end{tabular}

Source: PUPR Ministerial Decree No. 2/ PRT/M/2016

Analysis of location assessment based on criteria, indicators and parameters of slums in the Galesong Slum Area, then the level of slums, Other Considerations and Land Legality of the Galesong Area based on the criteria, indicators and parameters of slums in the Galesong Slum Settlement Area, the level of slums, other considerations and the legality of land in the Galesong area, namely: a ) Slum level: Severe Slum (Total Score 85); b) Other Considerations: High (Total Score 11); c) Land Legality: Illegal.

The process of developing fishermen's slum settlements in Galesong is conditioned by: the infrastructure service system has not run optimally, low awareness of environmental cleanliness, unstructured housing conditions, community participation in maintaining the residential environment is not optimal, and is inhabited by the dominant low-income community. In line with Soemadi's thinking (Tasrif Landoala, 2013) states that slums are part of a dirty city, buildings that do not meet health and health requirements and are inhabited by poor people with garbage disposal facilities, as well as clean water facilities that do not meet health requirements. This means that the Galesong slum settlement is a typology of slum settlements in coastal areas and is dominated by the poor and has not been served with basic facilities and infrastructure in accordance with minimum service standards.

The strategy for dealing with Galesong slums is measured based on a swot analysis. This swot matrix is used to formulate alternative strategies in handling slum areas by combining internal and external factors, which can be seen in the following table:

Table 5. Matrix of Potentials, Problems, Challenges, and Barriers

\begin{tabular}{l|l}
\hline Potency & $\begin{array}{l}\bullet \text { Close to the fishing industry kawasan } \\
\text { - Close to the port functional area } \\
\text { • Close to tourist areas }\end{array}$ \\
\hline
\end{tabular}




\begin{tabular}{|c|c|}
\hline & - Has potential for tourism sector development \\
\hline Problem & $\begin{array}{l}\text { - Unpatterned drainage channels } \\
\text { - Some areas do not have drainage channels } \\
\text { - Waste facilities are not served yet } \\
\text { - People throw garbage directly into the sea } \\
\text { - Don't have MCK yet } \\
\text { - Communities dispose of solid waste (feces) directly into the sea } \\
\text { - Environmental degradation of coastal areas and environmental pollution } \\
\text { - Do not have fire protection facilities } \\
\text { - Dominant communities occupy illegal land } \\
\text { - Lack of public awareness in keeping the environment clean } \\
\text { - Changing community behavior in conserving coastal areas } \\
\text { - Lack of public awareness in maintaining settlement infrastructure }\end{array}$ \\
\hline Opportunity & $\begin{array}{l}\text { - Enables the implementation of balanced urban area development through } \\
\text { environmental sustainability } \\
\text { - Development of urban settlements is oriented towards sustainable management of } \\
\text { coastal areas } \\
\text { - Development of new settlements and urban infrastructure integrated with } \\
\text { environmental management systems }\end{array}$ \\
\hline Obstacle & $\begin{array}{l}\text { - Implementation of development policies that have not been running effectively } \\
\text { conditions the weak control over the use of space so that it has an impact on the } \\
\text { development of slum areas that occupy coastal borders. } \\
\text { - The handling of slum areas in the Galesong area will have a fairly high social risk } \\
\text { because the dominant settlements occupy illegal land (squatters). } \\
\text { - Weak support for waste water management can be seen from the funding aspect from } \\
\text { district, provincial and central governments for the wastewater sub-sector } \\
\text { - At a macro level, the institutional management of the waste sub-sector is still low } \\
\text { - The limited ability to fund the Takalar Regency APBD has resulted in the budget } \\
\text { allocated for waste management being limited so that the budgeting adheres to a } \\
\text { priority system } \\
\text { - On a macro level, Takalar Regency does not yet have a Drainage Master Plan } \\
\text { - On a macro basis, budget constraints for the drainage sub-sector are a result of the } \\
\text { difficulty in proposing activities in the development and management of } \\
\text { environmental drainage }\end{array}$ \\
\hline
\end{tabular}

Source: Primary Data Management Results

The variables used to be able to assess the characteristics of individuals, objects, symptoms, which can be measured quantitatively or qualitatively in this study are divided into two, namely the dependent variable related to the existing and basic physical conditions of the Coastal Area, Kec. Galesong Kab. Takalar and the Independent Variable (X), namely:

Table 6. Independent Variable (X)

\begin{tabular}{c|l|l}
\hline No & \multicolumn{1}{|c}{ Variable } & \multicolumn{1}{c}{ Indicator } \\
\hline 1 & Social Aspect & $\begin{array}{l}\text { - Labor absorption } \\
\text { - Availability of service access } \\
\text { - Employment gaps }\end{array}$ \\
\hline 2 & Economic Aspect & $\begin{array}{l}\text { - Increasing people's income, } \\
\text { - Business opportunities } \\
\text { - Informal sector } \\
\text { - Income gap } \\
\text { - PDRB from sectors: transportation and communication, } \\
\text { finance, services, agriculture, industry, electricity, gas } \\
\text { and water, construction and trade. }\end{array}$ \\
\hline 3 & Environmental Aspects & $\begin{array}{l}\text { - Environmental conservation. } \\
\text { - Environmental pollution. }\end{array}$ \\
\hline
\end{tabular}


- Safety and comfort

Table 7. Dependent Variable (Y)

\begin{tabular}{|c|c|c|}
\hline No & Variabel & Indikator \\
\hline 1 & Basic Physical Aspect & $\begin{array}{l}\text { - Demographics of the population } \\
\text { - Availability of service access } \\
\text { - Employment gaps }\end{array}$ \\
\hline 2 & $\begin{array}{l}\text { Environmental Facilities and } \\
\text { Infrastructure }\end{array}$ & $\begin{array}{l}\text { - Road Conditions / Accessibility } \\
\text { - Drinking Water } \\
\text { - Drainage } \\
\text { - Garbage } \\
\text { - Waste Management } \\
\text { - Fire Protection }\end{array}$ \\
\hline 3 & Building Condition & $\begin{array}{l}\text { - Density Level } \\
\text { - Type of building } \\
\text { - Building Order } \\
\text { - Building Feasibility }\end{array}$ \\
\hline
\end{tabular}

\subsection{Discussion}

This study shows that the development process of fishermen's slum settlements in Galesong is conditioned due to: the infrastructure service system has not run optimally, low awareness of environmental cleanliness, unstructured housing conditions, community participation in maintaining the residential environment is not optimal, and is inhabited by the dominant MBR community. In line with Soemadi's thinking, slums are part of a dirty city, buildings that do not meet health and health requirements and are inhabited by poor people with garbage disposal facilities, as well as clean water facilities that do not meet health requirements (Pawitro, 2015). This means that the Galesong slum settlement is a typology of slum settlements in coastal areas and is dominated by the poor and has not been served with basic facilities and infrastructure in accordance with minimum service standards.

The strategy for handling Galesong slum settlements based on community participation is measured based on swot analysis. Based on the results of the strategy analysis using SWOT analysis, several coping strategies were born based on community empowerment. The strategy is carried out through: development of the potential of urban areas based on environmental sustainability, development of urban settlement areas followed by sustainable management of coastal areas, development of urban settlements and infrastructure that are integrated with environmental management systems, development of urban areas followed by controlling the use of productive lands. structuring and managing coastal areas in a sustainable manner, developing new settlements followed by structuring coastal areas, optimizing government supervision and control on violations of settlement area development along the coastal border, implementing regulations related to standards for residential area development, encouraging public awareness of the cleanliness of the community's environment, and increasing economic conditions of the community through strengthening the productive business system of fishing communities. In line with the idea (Noegroho, 2012), that community participation is important in development activities so that the results are more focused and optimally beneficial for residents.

The strategy for handling the Galesong fishing slum area based on community participation is carried out by: developing the potential of urban areas based on environmental sustainability, developing urban settlement areas followed by sustainable management of coastal areas, building settlements and urban infrastructure that is integrated with the environmental management system for regional development. urban areas followed by controlling the use of productive lands, structuring and managing coastal areas in a sustainable manner, developing new settlements followed by structuring coastal areas, optimizing government supervision and control over violations of residential area development along coastal borders, implementing regulations related to residential area development standards encouraging public awareness of the cleanliness of the community's environment, as well as improving the economic condition of the community through system strengthening productive business of fishing communities. 


\section{CONCLUSIONS AND SUGGESTIONS}

The typology of slum areas based on location characteristics shows the typology of slums in coastal areas and is a heavy slum which is dominated by the poor and has not been served by basic facilities and infrastructure in accordance with minimum service standards. As a research recommendation, for the government, dealing with slum areas requires a comprehensive and sustainable management concept. Socialization to the community related to healthy living behavior patterns and environmental conservation as well as community empowerment is needed in handling slum settlements. Tighter regulation and supervision from the government is needed on the development of slum areas. In future research, it is necessary to conduct a more in-depth study on preventing the development of slum areas so that they no longer develop more widely.

\section{REFERENCES}

Alfian. 2014. "Peran Dinas Cipta Karya Dan Tata Kota Dalam Penataan Perumahan Pemukiman Kawasan Garis Sempadan Sungai Studi Kasus Kelurahan Sungai Keledang Kecamatan Samarinda Seberang”. eJournal Ilmu Pemerintahan Vol.2, ISSN 2338-3651.

Astuti S, B dan Cakradiharja. (2017) Peranan Partisipasi Masyarakat dalam Perencanaan Pembangunan Desa, dalam http://pep3d.jabarprov.go.id/index.php/berita/artikel/77- peranan-partisipasi-masyarakatdalam-perencanaan-pembangunan-desa. Diunduh pada 9 Desember 2017.

Astuti, A. D. (2013). Partisipasi Masyarakat dalam Pembangunan Masyarakat Desa Melalui Mikro Pengolahan Susu Kambing Etawa di Tlogoguwo, Kaligesing, Purworejo, Jawa Tengah. Universitas Negeri Yogyakarta.

Andini, Ike. 2013. Sikap dan Peran Pemerintah Kota Surabaya Terhadap Perbaikan daerah Kumuh Di Kelurahan Tanah Keli kedinding Kota Surabaya. Jurnal Kebijakan dan Manajemen Publik Volume 01, Nomor 01.

Basri, Hasyim dkk. 2010. Model Penanganan Permukiman Kumuh (Studi Kasus Permukiman Kumuh Kelurahan Pontap Kecamatan Wara Timur Kota Palopo). Jurnal Arsitektur ITS. Seminar Nasional Perumahan dan Permukiman dalam Kota 2010.

Departemen Pekerjaan Umum. 2006. UU No. 26 Tahun 2007 Tentang Penataan Ruang.

David F.R. (2009). Manajemen Strategis Konsep, Edisi 12. Jakarta: Salemba Empat.

Fitria, N dan Setiawan, R. P. (2014). Identifikasi Karakteristik Lingkungan Permukiman Kumuh di Kelurahan Kapuk, Jakarta Barat. Jurnal Teknik Pomits. Vol. 3 No. 2 Hal 240-244

Fisu, A. A. (2016). Analisis dan Konsep Perencanaan Kawasan Pelabuhan Kota Penajam Sebagai Pintu Gerbang Kab. Penajam Paser Utara kalimantan Timur. PENA TEKNIK: Jurnal Ilmiah Ilmu-Ilmu Teknik, 1(2), 125-136.

Fisu, A. A., \& Marzaman, L. U. (2018). Pemetaan Partisipatif Kampung Pesisir Kelurahan Tallo Kota Makassar. To Maega: Jurnal Pengabdian Masyarakat, 1(1), 22-28.

Giyarsih, S.R. 2017. Regional Management of Areas with Indications of Urban Sprawl in the Surrounding Areas of Universitas Muhamadiyah Yogyakarta, Indonesia. Indonesian Journal of Geography 49 (1): 3541.

Kementerian Pekerjaan Umum dan Perumahan Rakyat Direktorat Jenderal Cipta Karya. 2015. Penanganan Kawasan Permukiman Kumuh: Panduan Penyelenggaraan Infrstruktur Permukiman.

Nursyahbani, Raisya dan Pigawati, Bitta. 2015. "Kajian Karakteristik Permukiman Kumuh di Kampung Kota (Studi Kasus : Kampung Gandekan Semarang).” Jurusan PWK, Fakultas Teknik, UNDIP.

Noegroho N. (2012).“Partisipasi Masyarakat Dalam Penataan Pemukiman Kumuh Di Kawasan Perkotaan”.Jurnal ComTech, Vol.3 No. 1: 23-33.

Pawitro U. (2015). Reklamasi Kawasan Pesisir Pantai: antara Pelestarian Lingkungan dan Ekonomi Kawasan. Prosiding Temu Ilmiah IPLBI. Vol. 4: 147-154.

Permen PUPR NO.2/PRT/M/2016.

Prayitno, Budi. 2014. Skema Inovatif Penanganan Permukiman Kumuh. Yogyakarta. Gadjah mada university press

Rorong, F., Rares, J. J., \& Ruru, J. M. (2017). Partisipasi Masyarakat dalam Pembangunan Infrastruktur di Desa Tolombukan Satu Kecamatan Pasan Kabupaten Minahasa Tenggara.

Salusu. (2015). Pengambilan Keputusan Stratejik: Untuk Organisasi Publik Dan Organisasi Nonprofit. Jakarta: PT. Gramedia.

Srinivas H. (2012). "Defining Squatter Settlements". GDRC Reseaarch Output E-036. Kobe, Japan: Global Development Research Center. 
Sugiyono. 2015. Metode Penelitian Kuantitatif, Kualitatif, Dan R.D. Bandung. Alfabeta, Cv.

Sri Kumala Dan Fitri Yusman. Kajian Karakteristik Dan Metode Penanganan Kawasan Kumuh (Studi Kasus: Kecamatan Semarang Timur, Kota Semarang). Jurnalteknikpwk Volume 3 Nomor 22014 Online:Http://Ejournal-S1.Undip.Ac.Id/Indeks.Php/Pwk.

Suroso, H., Hakim, A., \& Noor, I. (2014). Faktor-Faktor Yang Mempengaruhi Partisipasi Masyarakat Dalam Perencanaan Pembangunan Di Desa Banjaran Kecamatan Driyorejo Kabupaten Gresik. Jurnal Ilmu Administrasi, 17(1), 7-15.

UU No. 1 Tahun 2011 tentang Perumahan dan Kawasan Permukiman.

Warjio, \& Sigalingging, A. H. (2014). Partisipasi Masyarakat dalam Perencanaan Pembangunan (Studi Kasus pada Kecamatan Sidikalang Kabupaten Dairi). Jurnal Administrasi Publik, 2(2), 116-145. 